\title{
Seaweed biogeography of the mid-Atlantic coast of the United States*
}

\author{
R. B. Searles \\ Department of Botany, Duke University; Durham, N.C., USA
}

\begin{abstract}
The northern boundary of the warm temperate region of the mid-Atlantic coast of the United States is set at Cape Hatteras; the southern boundary lies at Cape Canaveral. There is some spillover of cool temperate species south of Cape Hatteras into North Carolina and spillover of warm temperate species south of Cape Canaveral toward Palm Beach. Elements of the warm temperate flora also extend into the northern Gulf of Mexico, but precise limits to the flora cannot be drawn there. Thirty-one species are endemic to the warm temperate flora. The inshore waters of North Carolina include approximately equal numbers of species with northern and southern centres of distribution; the species of the offshore waters have predominantly southern affinities, but also include most of the endemic species. Seasonal changes in the shallow water flora of North Carolina reflect eurythermal cool temperate and tropical elements in winter and summer respectively and a year-round warm temperate element. These groupings have been verified by experimental studies in which light and temperature were varied. The deep water flora is a summer flora dominated by perennial species. The inshore, eurythermal cool temperate and tropical species have a variety of cryptic stages by which they persist throughout the year.
\end{abstract}

\section{INTRODUCTION}

Study of the seaweeds* * of the mid-Atlantic coast of the United States has resulted in an increasing number of papers on seaweed biogeography in the region during the course of this century (Hoyt, 1920; Stephenson \& Stephenson, 1952; Humm, 1969; van den Hoek, 1975; Schneider, 1976; Kapraun, 1980; Searles \& Schneider, 1980). It is a coastline whose sandy shores have been characterized as inhospitable to seaweeds (van den Hoek, 1975) and Humm $(1969,1979)$ has suggested that it does not have a flora of its own, but only the species from adjacent regions which extend into or across the region. Those who have recognized a warm temperate flora along the mid-Atlantic coast have had difficulty specifying its boundaries, particularly the northern and western boundaries (Stephenson \& Stephenson, 1952; van den Hoek, 1975; Kapraun, 1980).

The purpose of this paper will be to draw together elements of studies made in recent years which contribute to our understanding of the limits of the region, to discuss

\footnotetext{
- Paper presented at the Seaweed Biogeography Workshop of the International Working Group on Seaweed Biogeography, held from 3-7 April 1984 at the Department of Marine Biology, Rijksuniversiteit Groningen (The Netherlands). Convenor: C. van den Hoek.

- The Cyanophyta are not included in this discussion since the range of species concepts in the group limit their use in biogeographical studies.
} 
the special characteristics of some of the plants occurring in it, and to suggest lines of future study which may further an understanding of the region and its seaweeds.

\section{THE GEOLOGIC ENVIRONMENT}

This mid-Atlantic coast is bordered on the north by the rocky shores of the New England states, the last rocky shores ending in Long Island Sound (Fig. 1). In the south it

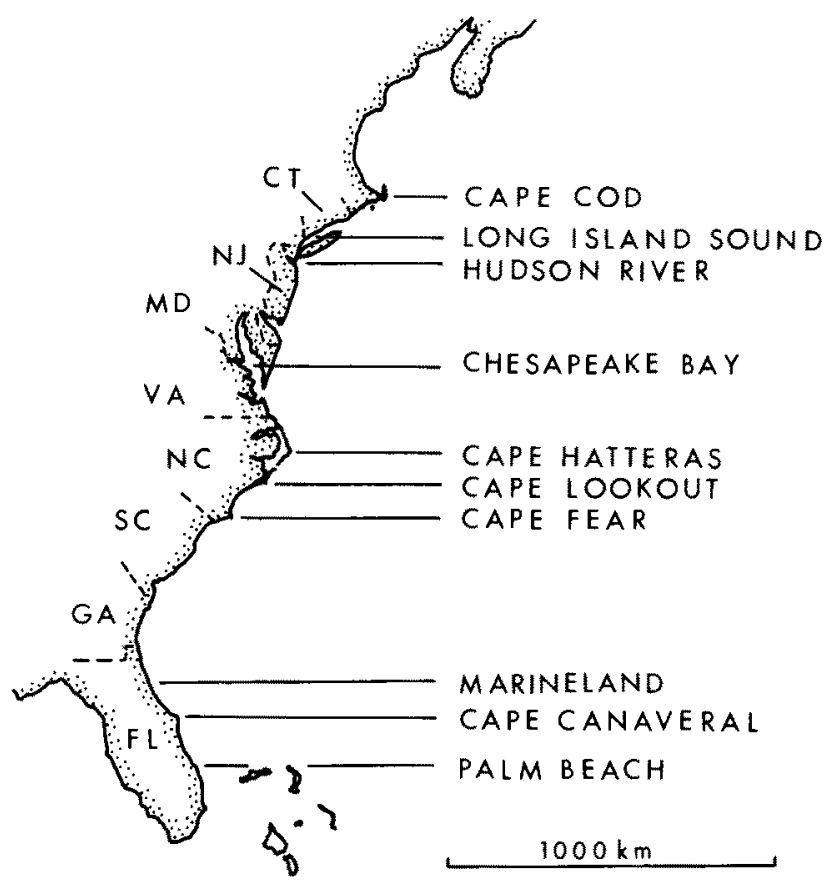

Fig. 1. Atlantic coast of the United States showing features mentioned in the text. CT, Connecticut; NJ, New Jersey; MD, Maryland; VA, Virginia; NC, North Carolina; SC, South Carolina; GA, Georgia; FL, Florida

abuts on the coral shores of southern Florida. The shoreline inbetween is characterized by sandy barrier islands and shallow sounds. The coast is punctuated by a series of capes, the most prominent of which is Cape Hatteras in North Carolina. Major rivers empty into the ocean through large bays such as the Chesapeake Bay, through the sounds, or almost directly into the sea in the case of the Cape Fear River. Offshore of the barrier islands is the continental shelf which is only a few kilometers wide at Cape Hatteras, but widens north and south of that cape to 100 or more kilometers off the New Jersey and Georgia coasts. In the south the shelf again narrows along the Florida coast.

Rocky intertidal shores of natural origin are almost completely absent along this coast. Intertidal rocks occur in a small area just to the north of Cape Fear and at Marineland in northern Florida. In shallow water, seaweeds therefore grow primarily on shell rubble, as epiphytes on seagrasses and other algae, or on solid substrates introduced by man: seawalls, jetties, groins, docks etc. South of Cape Hatteras there are 
offshore outcrops of sedimentary rock all the way into Florida which support the growth of seaweeds. There are also outcrops north of Cape Hatteras, but there are no reports of seaweeds from the continental shelf along that part of the coast. I have explored one outcrop just north of Cape Hatteras at a depth of 20 meters in mid-summer and found no seaweeds (unpublished data). The amount of rocky bottom varies along the coast because of sediment cover. Onslow Bay, between Cape Lookout and Cape Fear, and the coast near Palm Beach, Florida appear to have the most extensive outcrops. Onslow Bay lacks any input from major rivers. The only rivers emptying into the bay originate on the coastal plain, a region of deposition rather than erosion. All other parts of the region, except the Florida peninsula, receive effluent from rivers which originate in the piedmont or mountains and carry sediment from these erosive areas to the sea, where the sediment covers the rocks of the continental shelf.

\section{HYDROGRAPHIC ENVIRONMENT}

\section{Currents}

The dominant current in the region is the Florida Current, which originates in the Florida Straits between the southern tip of Florida and Cuba. As it flows north it is joined by the Antilles Current. After paralleling the outer edge of the continental shelf, the Florida Current moves offshore at Cape Hatteras and moves northeast as the Gulf Stream. North of Cape Hatteras, Virginia coastal water generally flows south and at Cape Hatteras turns offshore and parallels the Gulf Stream. The position of the Gulf Stream is not constant. In the summer it tends to move inshore bringing warm, clear water to the shelf. In the winter it is driven offshore by northerly winds and when this happens cold water from the north may move south past Cape Hatteras along the North Carolina coast (Gray \& Cerame-Vivas, 1963; Stefansson et al., 1971). Inshore currents south of Cape Hatteras are variable. South flowing geostrophic currents are periodically interrupted by inshore movement of the Florida Current which causes a northward flow (Bumpus, 1973).

There are three different kinds of important temperature transitions in the region. From north to south there is an abrupt change in water temperature at Cape Hatteras where the Florida Current meets the Virginia coastal water (Gray \& Cerame-Vivas, 1963). North-south temperature transitions of importance also occur at the edges of the region at Cape Canaveral and Cape Cod (Parr, 1933). The two other kinds of transitions in temperature are the transition from inshore to offshore waters and the transition from season to season. In the sounds of North Carolina water temperatures can exceed $30^{\circ} \mathrm{C}$ in the summer and drop to $0^{\circ} \mathrm{C}$ in the winter $(\mathrm{W}$. Kirby-Smith, data taken at the Duke Marine Laboratory, personal communication). In summer, bottom temperatures offshore are in the mid to upper $20^{\prime} \mathrm{s}$ on the inner and middle shelf and down to $10^{\circ} \mathrm{C}$ at the edge of the shelf at depths where light becomes limiting for algal growth. In the winter, bottom temperatures on the shelf are highest in mid-shelf, decreasing toward the edge of the shelf and toward shore (Stefansson \& Atkinson, 1967). Habitats in the sounds may, therefore, experience changes in temperature of $30^{\circ} \mathrm{C}$ or more through the seasons while the inner and mid-shelf will experience changes of near $15-18^{\circ} \mathrm{C}$ and at the shelf break the seasonal change in temperature will be $8-9^{\circ} \mathrm{C}$ (Stefansson et al., 1971). 


\section{Light}

Turbidity in the shallow sounds behind the barrier islands limits light penetration so that seaweeds do not generally grow more than 1-2 meters below the low tide line (Hoyt, 1920). Water clarity is greater offshore with seaweeds growing to depths of 90 meters (Schneider, 1976), but clarity can change markedly with in short periods of time, particularly in the nearshore, shallower environments. In the winter, light penetration is decreased due to storms which suspend sediments, the influx of sediments from river runoff, and increased amounts of phytoplankton. In the summer intrusions of Gulf Stream water tend to increase water clarity. The episodic nature of the changes in light penetration are shown in the data from Peckol \& Searles (1984) showing changes in light penetration at a midshelf station off Cape Lookout.

\section{THE BIOLOGICAL ENVIRONMENT}

\section{Competition for space}

The lack of hard substrates on this coast must make competition for space an important element in the ecology of the seaweeds, but there has been little study of this in the region. Richardson $(1979,1981,1982)$ studied some aspects of colonization by seaweeds in the sounds of North Carolina; and Peckol \& Searles (1983) have investigated colonization by seaweeds and interactions among seaweeds and sessile invertebrates on an offshore rock outcrop. In spite of the limited hard substrate in the region it still supports a flora of over 300 species and one can only speculate on the potential for a larger flora if additional rocky habitats were available.

\section{Grazers}

A relatively depauperate element of the fauna in the region is the herbivorous fish guild. There are many tropical fish in the waters south of Cape Hatteras; but many species of parrotfish (Scarideae) and surgeonfish (Acanthuridaeae), two of the most important groups of herbivorous fish from the tropics, do not occur north of the central Florida east coast (Briggs, 1958), or are present in low abundance in the region (S. W. Ross, personal communication). Grazing animals of importance in the region are the sea urchins, Lytechinus variegatus Lamarck and Arbacia punctata Lammarck. Peckol \& Searles' (1983) studies on the offshore rock outcrops suggest that these omnivorous grazers may be more effective in controlling the growth of sessile invertebrates than they are in controlling seaweeds. The coastal waters north of central Florida may, therefore, be a refuge from the intense grazing pressure of herbivorous fish which is common in the tropics.

\section{FLORISTIC AND BIOGEOGRAPHICAL BACKGROUND}

Study of seaweeds on the mid-Atlantic coast of the United States dates back over one hundred years, but the first major contribution to phycology in these waters began with Hoyt's (1920) investigations which were concentrated in North Carolina waters just after the turn of the century. In addition to cataloging 133 taxa from inshore and offshore 
waters, he noted both the marked seasonal shifts in the species present and the large number of species which were either at the northern or southern limits of their ranges in North Carolina. Since the work of Hoyt, subsequent investigators have increased the number of species known in the region to over 300 . The number of species recognized is in part a function of where one chooses to draw the regional boundaries.

After Hoyt's comments on the geographical relationships of the flora, the topic lay dormant until the Stephensons (1952) studied the intertidal communities at Marineland, Florida, Charleston, South Carolina and Beaufort, North Carolina. On the basis of the species present and the average monthly temperatures at these locations they characterized the region between Cape Canaveral and Cape Hatteras as warm temperate and suggested that it contained four elements: (a) eurythermic tropical species, (b) eurythermic cold-water species, (c) eurythermic cosmopolitan species and (d) mid-Atlantic species with distributions centered in the region. They predicted that elements (a) and (d) would predominate in the region. Humm (1969) characterized the region as a long transition zone between a Caribbean centered, tropical flora and a North Atlantic centred, cool/cold water flora. He said that elements of each flora extended different distances into or across the region, but recognized no species with a distribution centred in the region.

Van den Hoek (1975) was more specific and quantitative in describing the relationships of what he recognized as a warm temperate flora with the other floras in the North Atlantic. He indicated that the flora showed greatest similarity to the tropical western Atlantic flora to the south, but was a much smaller, depauperate flora which lacked many of the species of that tropical region. He recognized a sharp distinction between the warm temperate Carolinian region and the cold temperate Atlantic-Boreal region to the north. His data indicated that the warm temperate Carolinian and the tropical Atlantic regions both show greater similarities to the warm temperate MediterraneanAtlantic region to the east than to the northern floras. He also noted very low levels of endemism (five species) in the Carolinian region compared with the warm temperate Mediterranean-Atlantic region (40\% endemism) and the tropical Western Atlantic region (55\% endemism).

\section{RECENT DEVELOPMENTS}

\section{Limits of the region}

The boundaries of the region have been unclear and therefore the size and composition of the flora have been uncertain. The minimal boundaries appear to lie at Cape Canaveral in the south and Cape Hatteras in the north. Elements of the flora centred in the region extend south to Palm Beach, Florida and west into the Gulf of Mexico, arguing for possible inclusion of those areas. The coastline north of Cape Hatteras is either unclaimed by seaweed biogeographers (Stephenson \& Stephenson, 1952; van den Hoek, 1975), is included in the warm temperate region (Kapraun, 1980. Fig. 1), or is allied with the northern flora (Humm, 1979). The broader limits of the region would encompass over 500 species, the narrower limits approximately 320 species. 


\section{The northern boundary}

The weight of phycological evidence indicates that the northern limit of the warm temperate region ends at Cape Hatteras, a view in accord with that of zoogeographers (Briggs, 1974). Taylor (1957) stated that the flora as far south as New Jersey (where the sandy coastline begins) is boreal rather than tropical in its affinities. He recognized two assemblages of algae with northern, subarctic centers of distribution; one extended as far south as Cape Cod, the other reaching into Long Island Sound. A recent checklist of seaweeds from Connecticut and Long Island Sound, assembled by Schneider et al. (1979), lists 192 species. Thirtyfive percent of these are plants of northern affinities at their southern limit. This large northern element, in the absence of a comparable warm water element, supports Taylor's inclusion of this area in his boreal region.

The flora from Long Island Sound south to Cape Hatteras is documented in the reports of Zaneveld \& Willis (1974, 1976), Ott (1973), and Humm (1979). It includes just over 150 species. There is a single endemic species, three species at their northern limits of distribution, 34 species $(22 \%)$ at their southern limits of distribution and 30 species $(20 \%)$ which extend south through the region, spilling past Cape Hatteras, but go no further south than North Carolina. This large element of species with northern affinities and the absence of a significant element of southern species indicates that the area should not be included in the warm temperate region.

South of Cape Hatteras there is a striking change in the flora. The waters of North Carolina support over 300 species. Fifty-four percent of these reach their limit of distribution in North Carolina. One hundred thirty-four (44\%) reach their northern limit of distribution there and 30 species $(10 \%)$ reach their southern limit. The remainder are local endemics (14 species), species with disjunct or uncertain distributions (35 species), or species which range north and south of North Carolina (90 species).

The waters to the south have fewer species reported, 95 in South Carolina (Wiseman \& Schneider, 1976; Wiseman, 1978; Blair \& Hall, 1981) and 81 in Georgia (Chapman, 1971, 1973; Searles, 1980 and unpublished data). These are mostly species with warm water distributions; there are five species reaching northern limits of distribution in South Carolina and five in Georgia.

\section{Southern and western boundaries}

Stephenson \& Stephenson (1952) suggested Cape Canaveral as the boundary between tropical and warm temperate regions, a viewpoint supported by most zoogeographers (Briggs, 1974, pp. 61-64). Investigators at the Harbor Branch Foundation have recently reported 234 species of seaweeds in the waters south of Cape Canaveral to Palm Beach, Florida (Kerr, 1976; Eiseman, 1976, 1979; Eiseman \& Moe, 1981; Eiseman \& Norris, 1981; Hall \& Eiseman, 1981). Humm (1952) reported 43 species of seaweeds from Marineland, north of Cape Canaveral. Ninty-eight of the species from the waters just south of Cape Canaveral ( $42 \%$ ) are at their northern limit of distribution, giving the flora a distinctly tropical cast. Only four of the Marineland species are at their northern limit $(9 \%)$ and two are at their southern limits.

This data reinforces the suggestions that Cape Canaveral sets the boundary between tropical and warm temperate regions. The boundary is blurred slightly by the presence of seven species which were originally described as North Carolina endemics (Table 1) 
Table 1. Warm temperate endemic species from the east coast of the United States

\begin{tabular}{|c|c|}
\hline Taxa & Species \\
\hline Rhodophyta & $\begin{array}{l}\text { Porphyra carolinensis Coll \& Cox } \\
\text { Porphyra rosengurttii Coll \& Cox } \\
\text { Audouinella affinis (Howe \& Hoyt) Schneider } \\
\text { Audouinella hoytii (Collins) Schneider } \\
\text { Audouinella ophioglossa Schneider } \\
\text { Helminthocladia andersonii Searles \& Lewis } \\
\text { Scinaia incrassata Eiseman (1) } \\
\text { Dudresnaya patula Eisemann \& Norris (1) } \\
\text { Dudresnaya georgiana Searles } \\
\text { Mesophyllum sep. nov. Suyemoto \& Townsend (3) } \\
\text { Cirrulicarpus carolinensis Hansen } \\
\text { Trematocarpus papenfussii Searles } \\
\text { Hypnea volubilis Searles (2) } \\
\text { Petroglossum undulatum Schneider (2) } \\
\text { Gloioderma blomquistii Searles (2) } \\
\text { Gloioderma sp. nov. Searles (3) } \\
\text { Maripelta atlantica Eiseman (1) } \\
\text { Aquardhinula browneae (J. Agardh) DeToni (4) } \\
\text { Branchioglossum minutum Schneider (2) } \\
\text { Branchioglossum prostratum Schneider (2) } \\
\text { Calloseris halliae J. Ag. } \\
\text { Searlesia subtropica (Schneider) Schneider } \\
\text { Dipterosiphonia reversa Schneider }\end{array}$ \\
\hline Phaeophyta & $\begin{array}{l}\text { Giffordia sp. nov. Amsler ex Amsler \& Kapraun (3) } \\
\text { Streblonema invisible Hoyt } \\
\text { Onslowia endophytica Searles (2) (6) } \\
\text { Padina profunda Earle (5) }\end{array}$ \\
\hline Chlorophyta & $\begin{array}{l}\text { Codium carolinianum Searles (5) } \\
\text { Derbesia turbinata Howe \& Hoyt }\end{array}$ \\
\hline Xanthophyta & $\begin{array}{l}\text { Vaucheria acranda Ott \& Hommersand } \\
\text { Vaucheria adela Ott \& Hommersand }\end{array}$ \\
\hline \multicolumn{2}{|c|}{$\begin{array}{l}\text { Explanations: } \\
\text { (1) Endemic to the waters between Palm Beach Florida and Cape Canaveral. } \\
\text { (2) Range includes the waters between Palm Beach Florida and Cape Canaveral. } \\
\text { (3) Species as yet unpublished or in press. } \\
\text { (4) Florida distribution not certain, cast ashore. } \\
\text { (5) Range includes the northeast Gulf of Mexico (Earle, 1969; Cheney \& Dyer, 1974). } \\
\text { (6) Florida collections by E. C. Henry (personal communication). }\end{array}$} \\
\hline
\end{tabular}

and which now appear to spill over the Cape Canaveral boundary. Three species currently known only from the coast between Cape Canaveral and Palm Beach have also recently been reported (Eiseman, 1979; Eiseman \& Moe, 1981; Eiseman \& Norris, 1981).

In the Gulf of Mexico, Taylor (1955) has argued that the flora is characteristically tropical with changes to the north and west in the Gulf being due to impoverishment rather than replacement by a temperate flora. Earle (1969), on the basis of her studies of the Phaeophyta from the eastern Gulf, noted similarites between the winter flora in that 
area and the Carolinian flora. Edwards \& Kapraun (1973) and Kapraun (1974) working along the Texas and Louisiana shores also noted elements of the mid-Atlantic coast flora on those shores, but with a larger number of tropical species. Zoogeographers have also pointed out affinities between the faunas of the northern coast of the Gulf of Mexico and those of the mid-Atlantic coast (Briggs, 1974). There is, however, no consensus about the nature of the flora or its limits.

\section{Endemic species}

Although van den Hoek (1975) indicated only 5 endemic species in the region, there are now 31 species reported which have their centres of distribution in the region and are either limited to the region as narrowly defined, or extend a short distance into the tropical region (Table 1). These 31 species constitute $10 \%$ of the total flora as narrowly defined ( 320 species). This is a small proportion of endemism compared with the floras of the warm temperate Atlantic-Mediterranean region $(40 \%)$ or the tropical Atlantic region (55\%), but is comparable to the $11 \%$ endemism of the much more extensive cold temperate Atlantic-Boreal region reported by van den Hoek (1975).

\section{Differences between inshore and offshore floras}

The differences between the inshore and offshore floras have been well documented on the North Carolina coast where they are striking.

Approximately $2 / 3$ of the species, 204 of a total 303 species, occur in the shallow, coastal environment and an equal fraction, 194/303 live in the deeper, offshore waters. About half of the plants in shallow water, 109 species, do not occur in deep water and about half of those in deep water, 108 species, are restricted to deep water. That leaves one third of the flora, 96 species, which occurs in both shallow and deep water. Sixtythree species $(21 \%)$ of the flora in shallow water are at the northern limit of distribution and $29(10 \%)$ are at their southern limit. The plants in deep water include 113 species, $37 \%$ of the flora, at their northern limit of distribution and only 3,1\% of the flora, at the southern limit of distribution. The data becomes more striking if the eurybathyal species which occur in both deep and shallow water are eliminated and only the species restricted to deep or shallow water are considered. The shallow water habitats include 21 species at their northern limit of distribution and a similar number, 27 at their southern limits. In deep water the plants restricted to that environment are, in contrast, almost exclusively tropical, 75 of the species occurring at their northern limit. Only a single species restricted to deep water is at its southern limit of distribution and that species, Gigartina stellata (Stackh.) Batt. is represented by only a single anomalous collection (Schneider \& Searles, 1973).

\section{Seasonal changes in the flora}

The seasonal changes in the shallow water flora in the Carolinas were highlighted by the work of Hoyt (1920) and Williams (1948). They described a winter flora the conspicuous species of which had cool temperate, northern distributions and a summer flora with species having tropical, southern distributions. Kapraun \& Zechman (1982), in a detailed study of a jetty at Masonboro Inlet, North Carolina, suggested that there are 
three components to the flora there: a eurythermal cool temperate element in winter, a eurythermal tropical element in summer, and a warm temperate element which is observed all the year round. They did not break down the latter element on the basis of geographic range as Stephenson \& Stephenson (1952) had done.

Kapraun studied several shallow water species using light-temperature gradient tables and demonstrated a range of responses to combinations of those two factors which in general correspond to the observed phenologies of the plants in the field. Eurythermal species with cool temperate distributions, e.g. Polysiphonia urceolata (Lightf.) Grev., have maximal growth and reproduction in the winter in North Carolina, and show maximal growth at intermediate temperatures and maximum reproduction at low temperatures. Eurythermal tropical species, e.g. Polysiphonia ferulacea Suhr, have maximal growth and reproduction in the summer months and also show maximal growth and reproduction at high light and high temperature conditions in the cross gradient experiments. Warm temperate species, e.g. Polysiphonia denudata (Dillw.) Kutz., are observed year round in North Carolina and show greatest growth and reproduction at intermediate temperatures and light conditions (Kapraun, 1978b). Kapraun (1978b) has also shown differences between the light saturated growth responses of Polysiphonia denudata from North Carolina and those reported by Edwards (1970) for that species in Texas, suggesting that the Carolina populations are ecotypes adapted to lower levels of solar radiation. Kapraun has also shown (1978a) differences in the ecotypic responses to light levels and temperature of North Carolina populations of Callithamnion byssoides Arnott ex Harv. in Hook. and those demonstrated by Edwards (1971) in Texas populations.

Schneider (1975) showed that the offshore flora with its abundance of tropical species is a flora which has a peak development in mid-summer. The number of species and the biomass of plants decreases in the fall to a winter low and gradually increases through the spring and early summer. Nintynine percent of the species in that offshore flora were present in mid-summer. Species such as Grinnellia americana (C. Ag.) Harv. and Dasya baillouviana (Gmel.) Mont., which are characteristic members of the spring flora in shallow waters are infrequent in deep water, but they persist longer into the summer in deep water than they do in shallow water (personal observations).

The dominant species of the offshore flora, Sargassum filipendula C. Ag., Codium carolinianum Searles, Botryocladia occidentalis (Borg.) Kylin and the Dictyotalian taxa Zonaria tournefortii (Lamour.) Mont. and Lobophora variegata (Lamour.) Womers. (Schneider, 1976; Peckol \& Searles, 1983) all appear to be perennial plants which overwinter as holdfasts and basal branches (personal observations). Mechanisms of life history adaptations of species in shallow water have been studied and show more cryptic perennation. Fiore (1977) demonstrated that Hummia onusta (Kutz.) Fiore, which has a conspicuous sporophyte stage in spring, oversummers as an ectocarpoid, gametophytic plant. Richardson described a protonemal stage in Dictyota dichotoma (Huds.) Lamour. under winter conditions (1979), a cryptic filamentous stage in Dasya baillouviana in the summer and winter (1981) and a comparable creeping stage in Bryopsis plumosa (Huds.) C. Ag. in the summer (1982).

Peckol (1983) examined seasonal shifts in photosynthetic rates of two codominant species from an offshore rock outcrop. Lobophora variegata, a widespread tropical species, showed highest photosynthetic rates at ambient temperatures from January to 
May. Zonaria tournefortii, a species restricted to the Carolinas and Brazil, showed peak photosynthetic rates higher than those of Lobophora in May. These changes in photosynthetic rates which occur as the seasons and temperatures shift on the continental shelf may suggest the basis for the codominance of these two species in this habitat.

\section{OUTLOOK}

The descriptive, floristic phase of study on this coast is probably reaching a point of diminishing returns, although the individual species being discovered may continue to be of interest from a taxonomic and systematic point of view. The basic composition of the flora is, however, established. There is need for additional floristic, alpha taxonomic work in adjacent areas. Eiseman's work in deep water on the east coast of Florida and the work off North Carolina suggest that deep water studies in the Caribbean will be rewarding.

The low level of seaweed endemism in the region is interesting. Although low relative to seaweed floras in the regions to the south and in the eastern Atlantic, it is high relative to endemism in the fish population. Briggs (1974) states that there are only 6 endemic species or subspecies of fish in the region. One might think that the intermittent spacing of suitable substrates for algal growth in the region might lead to isolation and speciation. However, in spite of the patchy distribution of substrates, dispersal in some species is effective. Codium fragile subsp. tomentosoides (van Goor) Silva has moved south from Long Island Sound to the North Carolina coast in less than 25 years (Searles et al., 1984), demonstrating that the lack of substrate is not a serious problem to dispersal in that species. Studies of colonization in offshore habitats (Amsler \& Searles, 1980; Peckol \& Searles, 1983) indicate a limited ability of the dominant species in that habitat to colonize by spores. The whole question of dispersal and colonization by spores vs. vegetative fragmentation is unresolved and this could be an appropriate region in which to study it because of the patchy distribution of substrates and, therefore, the discontinuous populations of seaweeds.

Kapraun's demonstration of optimal growth and reproduction in some species in warm temperate water conditions is limited to plants from shallow water. Since many of the plants from offshore and most of those restricted to deep water have tropical centres of distribution, they might not be expected to show temperate water growth and reproductive optima. However, most of the endemic species of the region (21 of 33) are restricted to deep water and they may perhaps be adapted to the moderate, but seasonally cooler temperatures that occur on the continental shelf. Perhaps the endemic species and some of nonendemic species on the shelf will also show specialized growth and reproductive characteristics different from those of more southern populations if they are studied in experiments similar to those conducted by Kapraun on plants of shallow water.

Work on seaweeds in the region in the future should emphasize experimental studies which will allow us to determine how physiologically and genetically different plants are from those in adjacent regions and how their ranges are limited by both the physical and biological environments. 


\section{LITERATURE CITED}

Amsler, C. D. \& Searles, R. B., 1980. Vertical distribution of seaweed spores in a water column offshore of North Carolina. - J. Phycol. 16, 617-619.

Blair, S. M. \& Hall, M. O., 1981. Ten new records of deep water marine algae from Georgia and South Carolina. - Northeast Gulf Sci. 4, 127-130.

Briggs, J. C., 1958. A list of Florida fishes and their distribution. - Bull. Fla St. Mus. biol. Sci. 2, 223-318.

Briggs, J. C., 1974. Marine zoogeography. McGraw-Hill, New York, 475 pp.

Bumpus, D. F, 1973. A description of the circulation on the continental shelf of the east coast of the United States. - Prog. Oceanogr. 6, 111-157.

Chapman, R. L., 1971. The macroscopic marine algae of Sapelo Island and other sites on the Georgia coast. - Bull. Ga Acad. Sci. 29, 77-89.

Chapman, R. L., 1973. An addition to the macroscopic marine algal flora of Georgia. The genus Cladophora. - Bull. Ga Acad. Sci. 31, 147-150.

Cheney, D. P. \& Dyer, J. P. III, 1974. Deep-water benthic marine algae of the Florida "Middle Ground". - Mar. Biol. 27, 185-190.

Earle, S. A., 1969. Phaeophyta of the Eastern Gulf of Mexico, - Phycologia 7, 71-254.

Edwards, P., 1970. Field and culture observations on growth and reproduction of Polysiphonia denudata from Texas. - Brit. phycol. J. 5, 145-153.

Edwards, P., 1971. The effects of light intensity, day length and temperature on the growth and reproduction of Callithamnion byssoides. In: Selected papers in phycology. Ed. by B. Parker \& M. Brown. Allen Press, Lawrence, Kans., 163-173.

Edwards, P. \& Kapraun, D. F., 1973. Benthic marine algal ecology in the Port Aransas, Texas area.Contr. mar. Sci. Univ. Tex. 17, 15-52.

Eiseman, N. J., 1976. Benthic plants of the east Florida continental shelf. - A. Rep. Harbor Branch Fdn 1976, A1-A13.

Eiseman, N. J., 1979. Marine algae of the East Florida continental shelf. I. Some new records of Rhodophyta including Scinaia incrassata sp. nov. (Nemaliales, Chaetangiaceae). - Phycologia $18,355-361$.

Eiseman, N. J. \& Moe, R. L., 1981. Maripelta atlantica sp. nov. (Rhodophyta, Rhodymeniales) a new deep-water alga from Florida. - J. Phycol. 17, 299-308.

Eiseman, N. J. \& Norris, J. N., 1981. Dudresnaya patula sp. nov., an unusual deep water red alga from Florida. - J. Phycol. 17, 186-191.

Fiore, J., 1977. Life history and taxonomy of Stictyosiphon subsimplex Holden (Phaeophyta, Dictyosiphonales) and Farlowia onusta (Kützing) Kornmann in Kuckuck (Phaeophyta, Ectocarpales). - Phycologia 16, 301-311.

Gray, I. E. \& Cerame-Vivas, M. J., 1963. The circulation of surface waters in Raleigh Bay, North Carolina. - Limnol. Oceanogr. 8, 330-337.

Hall, M. O. \& Eiseman, N. J., 1981. The seagrass epiphytes of the Indian River, Florida. I. Species list with descriptions and seasonal references. - Botanica mar. 24, 139-146.

Hoek, C. van den, 1975. Phytogeographic provinces along the coasts of the northern Atlantic Ocean. - Phycologia 14, 317-330.

Hoek, C. van den, Breeman, A. M., Bak, R. P. M. \& Buurt, G. van, 1970. The distribution of algae, corals and gorgonians in relation to depth, light attenuation, water movement and grazing pressure in the fringing coral reef of Curaçao, Netherlands Antilles. - Aquat. Bot. 50, 1-46.

Hoyt, W. D., 1920. The marine algae of Beaufort, N. C. and adjacent regions. - Bull. Bur. Fish., Wash. 36, 367-556.

Humm, H. J, 1952. Notes on the marine algae of Florida. I. The intertidal rocks at Marineland. Stud. Fla State Univ. 7, 17-23.

Humm, H. J., 1969. Distribution of marine algae along the Atlantic coast of North America. Phycologia 7, 43-53.

Humm, H. J., 1979. The marine algae of Virginia. Univ. Press of Virginia, Charlottesville, 263 pp.

Kapraun, D. F., 1974. Seasonal periodicity and spatial distribution of benthic marine algae in Louisiana. - Contr. mar. Sci. Univ. Tex. 18, 139-167. 
Kapraun, D. F., 1978a. Field and culture studies on growth and reproduction of Callithamnion byssoides (Rhodophyta, Ceramiales) in North Carolina. - J. Phycol. 14, 21-24.

Kapraun, D. F, 1978b. Field and culture studies on selected North Carolina Polysiphonia species.Botanica mar. 21, 143-153.

Kapraun, D. F, 1980. Floristic affinities of North Carolina inshore benthic marine algae. Phycologia 19, 245-252.

Kapraun, D. F. \& Zechman, F. W., 1982. Seasonality and vertical zonation of benthic marine algae on a North Carolina coastal jetty. - Bull. mar. Sci. Gulf Caribb. 32, 702-714.

Kerr, G. A., 1976. Indian River coastal zone study inventory. - A. Rep. Harbor Branch Consortium Indian River Coastal Zone Study 2, 1-105.

Ott, F. D., 1973. The marine algae of Virginia and Maryland including the Chesapeake Bay area. Rhodora 75, 258-296.

Parr, A. E., 1933. A geographic ecological analysis of the seasonal changes in temperature conditions in shallow water along the Atlantic coast of the U.S. - Bull. Bingham oceanogr. Coll. 4 (3), $11-42$.

Peckol, P., 1983. Seasonal physiological responses of two brown seaweed species from a North Carolina continental shelf habitat. - J. exp. mar. Biol. Ecol. 72, 147-155.

Peckol, P. \& Searles, R. B., 1983. Effects of seasonality and disturbance on population development in a Carolina continental shelf community. - Bull. mar. Sci. Gulf Caribb. 33, 67-86.

Peckol, P. \& Searles, R. B., 1984. Temporal and spatial patterns of growth and survival of invertebrate and algal populations of a North Carolina continental shelf community. - Estuar. coast. Shelf Sci. 18, 133-143.

Richardson, J. P., 1979. Overwintering of Dictyota dichotoma (Phaeophyceae) near its northern distribution limit on the east coast of North America. - J. Phycol. 15, 22-26.

Richardson, J. P., 1981. Persistence and development of Dasya baillouviana (Gmelin) Montagne (Rhodophyceae, Dasyaceae) in North Carolina. - Phycologia 20, 385-391.

Richardson, J. P., 1982. Life history of Byropsis plumosa (Hudson) Agardh (Chlorophyceae) in North Carolina, USA. - Botanica mar. 25, 177-183.

Schneider, C. W., 1975. Spatial and temporal distributions of benthic marine algae on the continental shelf of the Carolinas. Ph. D. thesis, Duke Univ., Durham, N.C., 196 pp.

Schneider, C. W., 1976. Spatial and temporal distributions of benthic marine algae on the continental shelf of the Carolinas. - Bull. mar. Sci. Gulf Caribb. 26, 133-151.

Schneider, C. W. \& Searles, R. B., 1973. North Carolina marine algae. II. New records and observations of the benthic offshore flora. - Phycologia 12, 201-211.

Schneider, C. W., Suyemoto, M. M. \& Yarish, C., 1979. An annotated checklist of Connecticut seaweeds. - Bull. geol. nat. Hist. Surv., Conn. 108, 1-20.

Searles, R. B., 1981. Seaweeds from Gray's Reef, Georgia. - Northeast Gulf Sci. 5, 45-48.

Searles, R. B., Hommersand, M. H. \& Amsler, C. D., 1984. The occurence of Codium fragile subsp. tomentosoides and C. taylorii (Chlorophyta) in North Carolina. - Botanica mar. (In press).

Searles, R. B. \& Schneider, C. W., 1980. Biogeographic affinities of the shallow and deep water benthic marine algae of North Carolina. - Bull. mar. Sci. Gulf Caribb. 30, 732-736.

Stephenson, T. A. \& Stephenson, A., 1952. Life between the tide-marks in North America. II. Northern Florida and the Carolinas. - J. Ecol. 40, 1-49.

Stefansson, U. \& Atkinson, L. P., 1967. Physical and chemical properties of the shelf and slope waters off North Carolina. - Tech. Rep. Duke Univ. Mar. Lab., Beaufort, North Carolina, 230 pp.

Stefansson, U., Atkinson, L. P. \& Bumpus, D. F., 1971. Hydrographic properties and circulation of the North Carolina shelf and slope waters. - Deep Sea Res. 18, 383-420.

Taylor, W. R., 1955. Marine algal flora of the Caribbean and its extension into neighboring seas. In: Essays in the natural sciences in honor of Captain Allan Hancock. Univ. of Southern California Press, Los Angeles, 259-277.

Taylor, W. R., 1957. Marine algae of the northeastern coast of North America. Univ. of Michigan Press, Ann Arbor, 509 pp.

Williams, L. G., 1948. Seasonal alternation of marine floras at Cape Lookout, North Carolina. - Am. J. Bot. 35, 682-695,

Wiseman, D. R., 1978. Benthic marine algae. In: An annotated checklist of the biota of the coastal zone of South Carolina. Ed. by R. G. Zingmark. Univ. of South Carolina Press, Columbia, 23-36. 
Wiseman, D. R. \& Schneider, C. W., 1976. Investigations of the marine algae of South Carolina. I. New records of Rhodophyta. - Rhodora 78, 516-524.

Zaneveld, J. S. \& Willis, M. W., 1974. The marine algae of the American coast between Cape May, New Jersey, and Cape Hatteras, North Carolina. II. The Chlorophycophyta. - Botanica mar. 17, $65-81$.

Zaneveld, J. S. \& Willis, W. M., 1976. The marine algae of the American coast between Cape May, N. J. and Cape Hatteras, N. C. III. The Phaeophycophyta. - Botanica mar. 19, 33-46. 